\title{
Evolutionary freedom in the regulation of the conserved itaconate cluster by Ria 1 in related Ustilaginaceae
}

\author{
Elena Geiser ${ }^{1,2 \dagger} \cdot \mathbb{0}$, Hamed Hosseinpour Tehrani ${ }^{1 \dagger}$, Svenja Meyer ${ }^{1}$, Lars M. Blank ${ }^{1 *}$ and Nick Wierckx ${ }^{1}$
}

\begin{abstract}
Background: Itaconate is getting growing biotechnological significance, due to its use as a platform compound for the production of bio-based polymers, chemicals, and novel fuels. Currently, Aspergillus terreus is used for its industrial production. The Ustilaginaceae family of smut fungi, especially Ustilago maydis, has gained biotechnological interest, due to its ability to naturally produce this dicarboxylic acid. The unicellular, non-filamentous growth form makes these fungi promising alternative candidates for itaconate production. Itaconate production was also observed in other Ustilaginaceae species such as U. cynodontis, U. xerochloae, and U. vetiveriae. The investigated species and strains varied in a range of $0-8 \mathrm{~g} \mathrm{~L}^{-1}$ itaconate. The genes responsible for itaconate biosynthesis are not known for these strains and therefore not characterized to explain this variability.

Results: Itaconate production of 13 strains from 7 species known as itaconate producers among the family Ustilaginaceae were further characterized. The sequences of the gene cluster for itaconate synthesis were analyzed by a complete genome sequencing and comparison to the annotated itaconate cluster of U. maydis. Additionally, the phylogenetic relationship and inter-species transferability of the itaconate cluster transcription factor Ria 1 was investigated in detail. Doing so, itaconate production could be activated or enhanced by overexpression of Rial originating from a related species, showing their narrow phylogenetic relatedness.
\end{abstract}

Conclusion: Itaconate production by Ustilaginaceae species can be considerably increased by changing gene cluster regulation by overexpression of the Ria1 protein, thus contributing to the industrial application of these fungi for the biotechnological production of this valuable biomass derived chemical.

Keywords: Activation of silent cluster, (S)-2-hydroxyparaconate, (S)-2-hydroxyparaconic acid, Itaconic acid, Itatartarate, Secondary metabolites, Transcription factors, Basidiomycota, Ustilago maydis

\section{Background}

Secondary metabolites are organic, naturally produced, bioactive compounds with a low molecular weight, that are produced by fungi, bacteria, and plants via pathways not belonging to the primary metabolism of this organism $[1,2]$. In 2000, a literature survey identified more than

\footnotetext{
*Correspondence: lars.blank@rwth-aachen.de

†Elena Geiser and Hamed Hosseinpour Tehrani have contributed equally to this work

${ }^{1}$ iAMB - Institute of Applied Microbiology, ABBt - Aachen Biology and Biotechnology, RWTH Aachen University, Worringerweg 1,

52074 Aachen, Germany

Full list of author information is available at the end of the article
}

23,000 already discovered secondary metabolites mainly from the fungal kingdom [1, 3]. Closely related species usually produce related compounds and each compound is produced in a highly-narrowed taxonomy [2, 4]. Genes coding for the biosynthesis of secondary metabolites are usually co-localized in a gene cluster with a size of approximately over 10,000 bp depending on the complexity of the metabolite and regions of non-coding base pairs of up to 2000 bp between the coding genes $[2,5,6]$. In cases of polyketide synthases these regions are more extended [7]. These clusters contain genes coding for corresponding biosynthesis enzymes and transporters, regulatory proteins like transcription factors, and optionally modifying 
enzymes. Secondary metabolite clusters are often controlled by a complex regulatory network [8]. Several levels of regulation exist, which allow the organism to respond to various environmental influences. Transcription of these clusters can be regulated either by specific/narrowdomain or by global/broad-domain transcription factors or regulators or a combination thereof. Alternatively, regulation can be chromatin-mediated by histone acetylation or methylation [8].

Itaconate and its lactone (S)-2-hydroxyparaconate are examples of secondary metabolites. Itaconate is produced by fungi like Aspergillus terreus and Ustilago maydis, but also by less well-known Ustilaginaceae species, such as Ustilago cynodontis, Ustilago vetiveriae, and Ustilago xerochloae [9-12]. Itaconate has industrial applications as a co-monomer, for example in the production of acrylonitrile-butadiene-styrene and acrylate latexes in the paper and architectural coating industries [13]. According to an independent evaluation report of the U.S. Department of Energy (DoE) in 2004 [14], itaconate was assigned to be among the top 12 building blocks with a high biotechnological potential, enabling a conversion into a range of new interesting molecules such as 2-or 3-methyltetrahydrofuran with applications as novel biofuels $[15,16]$. Recent studies showed that genes for the biosynthesis of itaconate are co-localized in the genome and co-regulated in $U$. maydis [17], and therefore fulfilling the main criteria to be a secondary metabolite. $U$. maydis' itaconate cluster (GenBank: KT852988.1) contains two itaconate biosynthesis genes UMAG_tad1 and UMAG_adi1 encoding a trans-aconitate decarboxylase (Tad1) and an aconitate- $\Delta$-isomerase (Adi1), and two transporter genes $U M A G \_i t p 1$ and $U M A G \_m t t 1$ encoding an itaconate transport protein (Itp1) and a mitochondrial tricarboxylate transporter (Mtt1), respectively (Fig. 1). Their expression is co-regulated by the transcriptional regulator Ria1, also encoded in this cluster, which is considered as an itaconate cluster specific/ narrow domain transcription factor, triggering the transcription of the itaconate biosynthesis genes [17]. Overexpression of UMAG_ria1 upregulated the expression of biosynthesis core-cluster genes and transporters [17].

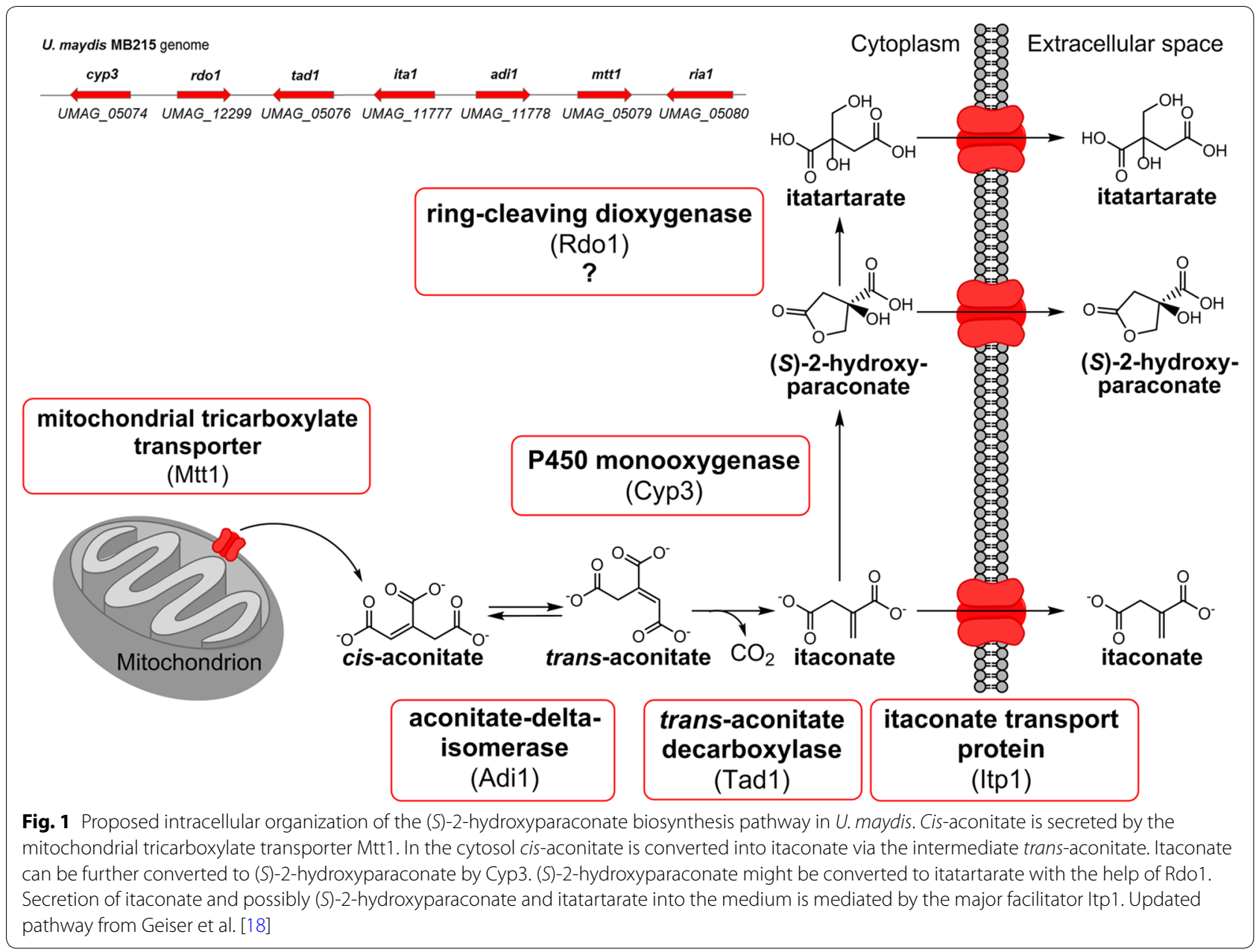


Additionally, the (S)-2-hydroxyparaconate biosynthesis gene UMAG_cyp3 encoding the cytochrome P450 family 3 monooxygenase Cyp3 and UMAG_rdo1 encoding a putative ring cleaving dioxygenase are adjacent to the itaconate gene cluster of $U$. maydis, the former of which converts itaconate to $(S)$-2-hydroxyparaconate [18]. Further, it was reported by Guevarra and Tabuchi that $(S)$ 2-hydroxyparaconate is converted to itatartarate by a lactonase [11, 19]. UMAG_cyp3 and UMAG_rdo1 are not part of the core cluster and not directly upregulated by overexpression of UMAG_ria1 [17]. However, all itaconate cluster genes including the two adjacent to the core cluster, UMAG_cyp3 and UMAG_rdo1, are strongly upregulated during teliospore formation in the late biotrophic growth stage during plant colonization [20-22].

The number of so far undiscovered secondary metabolites produced by enzymes encoded by cryptic or orphan gene clusters are innumerably high [23, 24]. However, the availability of numerous whole fungal genome sequences and in silico gene prediction by bioinformatic algorithms, such as SMURF [25], MiBiG [26], antiSMASH [27], and FungiFun [28], allow the identification of these cryptic gene clusters. These bioinformatic tools enable 'genome mining' via comparison of protein sequence and structure homology. Traditional ways of activating the expression of secondary metabolites clusters include the variation in the cultivation conditions, such as medium, $\mathrm{pH}$, temperature, aeration, or light, or co-cultivation with other microbes to simulate the natural expression conditions [8]. Often these physiological or ecological triggers are not sufficient to activate these clusters, and therefore several strategies have been developed to induce undiscovered silent secondary metabolite cluster [8]. The most prominent strategies are genetic engineering approaches: the overexpression of a cluster-specific transcription factor gene allowing the increased expression of the whole cluster [24]. In this case, the overexpression of the enzymes encoded within the cluster leads to diverse products, a potential challenge for natural product production $[18,24]$. In addition, the endogenous promoters of secondary metabolism biosynthesis genes can be exchanged for strong inducible or constitutive promoters or global regulators can be overexpressed or deleted. A prominent example of the activation of a silent gene cluster is the overexpression of the transcriptional regulator gene apdR in Aspergillus nidulans, which induced the expression of all cluster genes, leading to the discovery of the cytotoxic aspyridones [24].

Itaconate production is naturally induced by nitrogen limitation in $U$. maydis and was also observed in other related Ustilaginaceae species such as $U$. cynodontis, $U$. xerochloae, $U$. vetiveriae that show high potential to be promising and effective itaconate producers $[10,12,29]$.
However, the investigated species and strains varied in their product spectra and the amount of secreted product. Among the species, individual strains of $U$. maydis differed highly in their itaconate and (S)-2-hydroxyparaconate production [10]. Some of the species investigated, for example $U$. vetiveriae strain CBS 131474, produced itaconate or (S)-2-hydroxyparaconate only with glycerol as carbon source. Also, itaconate production varied depending on extracellular $\mathrm{pH}$. While in wild type $U$. maydis itaconate production is only possible in the $\mathrm{pH}$ range of 5-7, $U$. cynodontis strains also produce itaconate at $\mathrm{pH}$ values below 3 . The genes responsible for itaconate biosynthesis and how they are regulated to explain this variation in production levels and environmental inputs are not known for these specific strains.

In the current study, 13 itaconate producers of the Ustilaginaceae family were further characterized towards their itaconate cluster sequence-function relationship. The itaconate gene clusters of these strains were identified by genome sequencing [29] and comparison to the annotated itaconate cluster of $U$. maydis strain MB215. To explore the evolutionary conservation of regulation of the itaconate cluster in respect to itaconate production by members of the Ustilaginaceae family, the phylogenetic relationship and inter-species transferability of the itaconate cluster transcription factor Ria1 was investigated. Itaconate production could be activated or enhanced by overexpression of Rial originating from related species. This is the first time that activation of silent itaconate clusters by overexpression of a cluster-specific transcription factor in Ustilaginaceae species other than $U$. maydis is shown.

\section{Results and discussion}

\section{Variation in itaconate and (S)-2-hydroxyparaconate production among Ustilaginaceae}

Previous studies showed a high variation in natural itaconate production among related Ustilaginaceae species cultured on glucose and glycerol as carbon sources $[10,12]$. Besides their varying amounts of product and product spectrum, they also differed in their efficiency of carbon utilization. Some of the species produced itaconate only on a single carbon source like glycerol or glucose. These differences motivated us to investigate itaconate and derivates production on glucose and glycerol in more detail (Fig. 2, Additional file 1: Fig. S1). $U$. maydis $\Delta U m a g \_$rial was used as a negative control, since the transcriptional regulator gene rial is deleted and therefore itaconate production abolished. In $U$. maydis strain AB33P5A five extracellular proteases are deleted [30]. With these deletions, the strain is well suited for the secretion of heterologous or intrinsic extracellular biomass degrading CAZymes. This strain would be an 


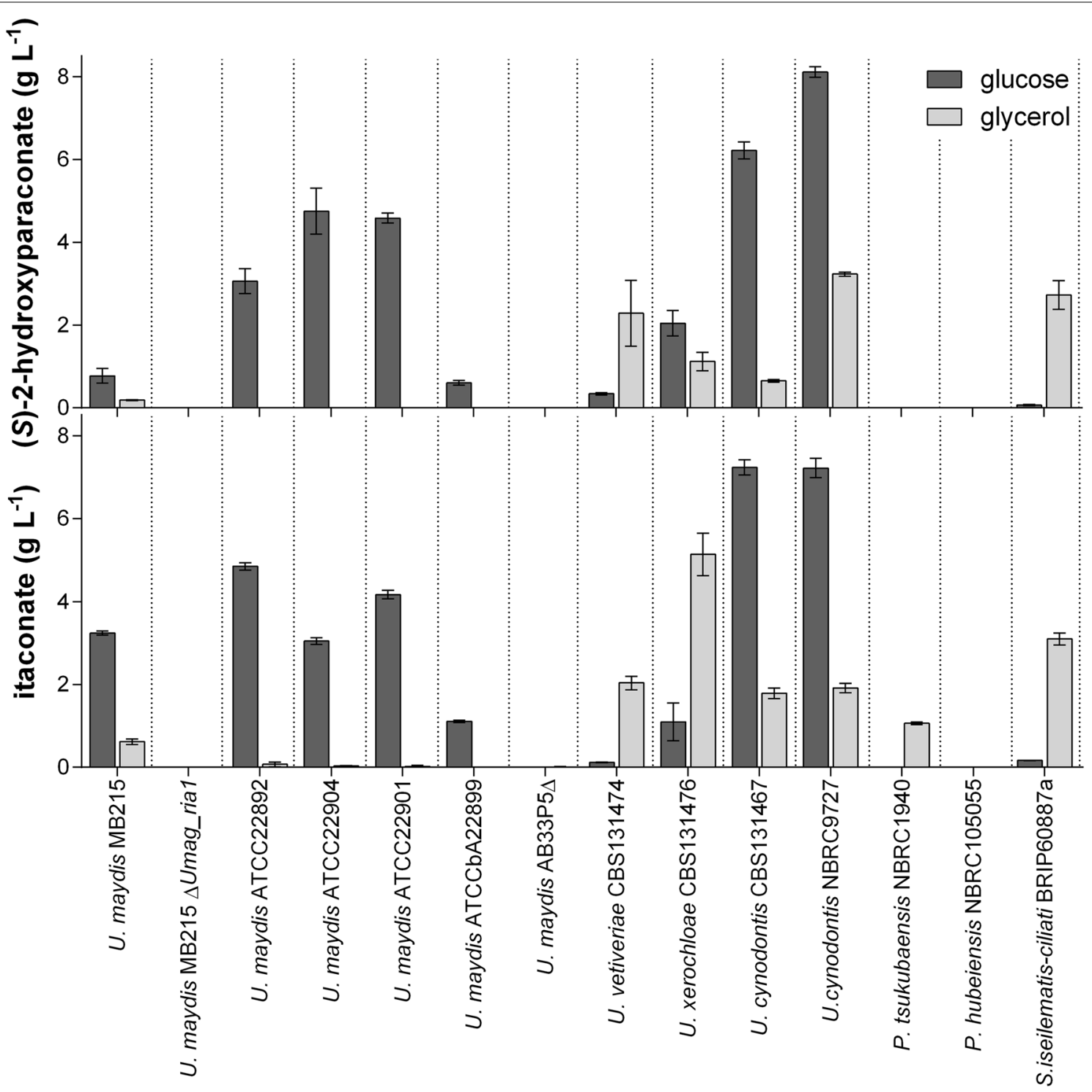

Fig. 2 Itaconate and (S)-2-hydroxyparaconate production by various species in the Ustilaginaceae cultivated on glucose and glycerol. Itaconate and (S)-2-hydroxyparaconate concentrations after $120 \mathrm{~h}$ or $384 \mathrm{~h}$ System Duetz ${ }^{\circledR}$ cultivations in screening medium with glucose or glycerol, respectively. The U. maydis $\triangle$ Umag_ria1 mutant derived from wild type strain MB215 was used as a negative control. Error bars indicate standard deviation from the mean $(n=3)$

optimal candidate for the synthesis of itaconate or other valuable chemicals directly from biomass-derived substrates [31]. However, it does not produce itaconate and the lack of extracellular proteases significantly reduces the growth rate of this mutant.

All wild type strains consumed at least $50 \%$ of the glucose in the $120 \mathrm{~h}$ except of $U$. maydis AB33P5 5 , which utilized 40\% (Additional file 2: Fig. S2). The growth on glycerol is slower in comparison to glucose, therefore samples were taken after $384 \mathrm{~h}$. At this time point, all strains consumed at least $30 \%$ of the glycerol, except of
U. maydis $\mathrm{AB} 33 \mathrm{P} 5 \Delta$, which used 13\% (Additional file 2: Fig. S2). Most $U$. maydis strains produced itaconate only on glucose as the carbon source, whereas $U$. vetiveriae, P. tsukubaensis, and S. iseilematis-ciliati did so only on glycerol. $U$. cynodontis and $U$. xerochloae produced itaconate on both carbon sources. U. maydis AB33P5A, $U$. maydis $\Delta U m a g$ rial, and $P$. hubeiensis did not produce itaconate at all. Since $(S)$-2-hydroxyparaconate and itatartarate are derivatives from itaconate [11], the production of these compounds was also investigated. (S)2-hydroxyparaconate production of the tested strains 
on glucose and glycerol was similar to itaconate production (Fig. 2), with the exception of P. tsukubaensis, which only produced itaconate. Also, estimated itatartarate production levels showed a similar trend compared to (S)-2-hydroxyparaconate production except for $S$. iseilematis-ciliati, which did not to produce itatartarate (Additional file 1: Fig. S1). Previous studies showed a negative correlation between itaconate and malate production [12], therefore malate production was also determined. All strains produced malate on glucose and glycerol except for $U$. maydis AB33P5 $\Delta$ and $S$. iseilematis-ciliati, which produced malate only on glycerol (Additional file 1: Fig. S1). In general $U$. maydis strains showed the highest malate titers. These results are in accordance with our previous study [10].

A possible reason for these varying titers of itaconate and its derivatives could be differences in the sequences of the itaconate and (S)-2-hydroxyparaconate biosynthesis genes, or the genetic inventory of these genes. Furthermore, different regulation or relative expression levels of the biosynthesis genes could cause varying production $[1,8]$. Due to the targeted disruption of the genes encoding its five proteases, $U$. maydis strain AB33P5 $\Delta$ is a slow growing strain in comparison to wild type and other Ustilaginaceae strains, possibly caused by different timing of the strains concerning $\mathrm{C}$ - or $\mathrm{N}$-source utilization or their growth rate [32]. To gain a deeper understanding of the sequence-function relationship between itaconate/(S)-2-hydroxyparaconate biosynthesis genes and production, the genomes of 13 Ustilaginaceae were analyzed and genes related to synthesis of these secondary metabolites annotated and characterized.

\section{Genetic differences in the itaconate biosynthesis cluster}

The Whole Genome Shotgun sequences of Ustilago maydis MB215 (DSM17144), Ustilago maydis ATCC 22892, Ustilago maydis ATCC22904, Ustilago maydis ATCC22901, Ustilago maydis ATCCbA22899, Ustilago maydis AB33P5A, Ustilago vetiveriae CBS131474, Ustilago xerochloae CBS131476, Ustilago cynodontis CBS131467, Ustilago cynodontis NBRC9727, Pseudozyma tsukubaensis NBRC1940, Pseudozyma hubeiensis NBRC105055, and Sporisorium iseilematis-ciliati BRIP60887a have been deposited in DDBJ/ ENA/GenBank [29]. Their accession numbers are listed in "Methods". To find the genes responsible for itaconate and (S)-2-hydroxyparaconate biosynthesis in these sequenced strains, the protein sequences encoded in the $U$. maydis MB215 itaconate biosynthesis cluster (GenBank KT852988.1) were used as queries against the Whole Genome Shotgun sequences database using the tBLASTn algorithm $[18,33]$. Multiple hits with neighboring genes were defined as putative itaconate clusters.
For cluster annotation, the highest resulting homologous sequences were further analyzed using the online tool "Augustus gene prediction" to identify start/stop codons and exons [34], followed by manual curation. Furthermore, protein sequences of $U$. maydis MB215 were compared to the predicted proteins of the investigated Ustilaginaceae using the global protein sequence multiple alignment tool (BLOSUM 62) [35] in Clone Manager 9 Professional Edition. The protein sequence identity of the investigated Ustilaginaceae proteins compared to the itaconate cluster of reference strain $U$. maydis MB215 is presented in Fig. 3b. Additionally, the phylogenetic tree based on the DNA sequences of itaconate clusters of different Ustilaginaceae indicates the phylogenetic relationship among the chosen strains (Fig. 3a).

Exact phylogenetic classification among Ustilaginaceae is challenging, with several species being renamed based on new analysis of indicator genes such as nuclear ribosomal RNA genes [39-41]. Wang et al. especially mentioned that strains in the genus Pseudozyma have an uncertain phylogenetic position due to the taxonomic confusion between their teleomorphic genera [39]. Therefore, a phylogenetic relation is shown based on the DNA sequence of the itaconate cluster (Fig. 3a).

In all sequenced organisms except $P$. tsukubaensis and P. hubeiensis, the complete gene cluster for itaconate synthesis and conserved synteny of all genes (gene orientation and chromosome) were identified (Fig. 3b). The cluster in P. tsukubaensis does not contain rdo1 and cyp3. For these two genes no likely homologous candidate was found elsewhere in genome, explaining the lack of $(S)$ 2-hydroxyparaconate and itatartarate production in this strain (Fig. 2). In P. hubeiensis, $m$ tt1 is not present in the itaconate cluster or its direct surrounding DNA regions. In $U$. maydis MB215, deletion of UMAG_mtt1 led to a strong decrease in itaconate production [17]. This transporter, which putatively shuttles malate and cis-aconitate between the mitochondria and the cytoplasm, is the rate-limiting step in itaconate biosynthesis in $U$. maydis MB215 [42]. Since itaconate formation was not completely abolished by Umag_mtt1 deletion in $U$. maydis, most likely other less specialized, and therefore less efficient, transport proteins substituted its function, as most eukaryotic mitochondrial transporters have a diverse substrate spectrum with different affinities [43]. At least one similar mitochondria tricarboxylate transporter gene is present in the genome of $P$. hubeiensis, which could take over the function of Mtt1. This gene showed $54 \%$ sequence similarity on protein level in comparison to Umag_mtt1 and 98\% to Umag_02365 upon tBLASTn analysis [33]. The latter gene, Umag_02365, is known to be one of two related mitochondrial citrate transporters in $U$. maydis, with redundant function to Umag_mtt1 

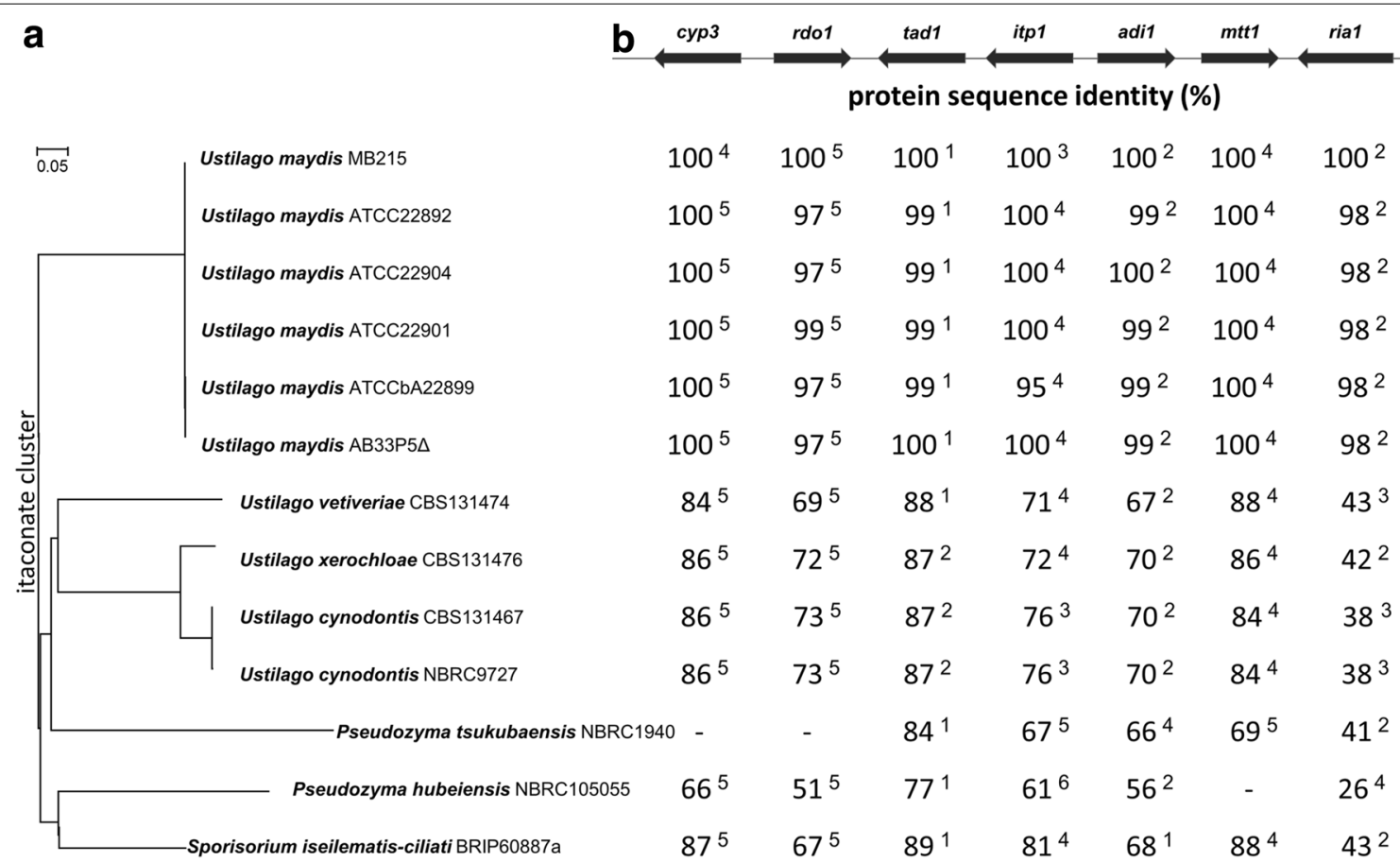

$\begin{array}{ccccccc}100^{4} & 100^{5} & 100^{1} & 100^{3} & 100^{2} & 100^{4} & 100^{2} \\ 100^{5} & 97^{5} & 99^{1} & 100^{4} & 99^{2} & 100^{4} & 98^{2} \\ 100^{5} & 97^{5} & 99^{1} & 100^{4} & 100^{2} & 100^{4} & 98^{2} \\ 100^{5} & 99^{5} & 99^{1} & 100^{4} & 99^{2} & 100^{4} & 98^{2} \\ 100^{5} & 97^{5} & 99^{1} & 95^{4} & 99^{2} & 100^{4} & 98^{2} \\ 100^{5} & 97^{5} & 100^{1} & 100^{4} & 99^{2} & 100^{4} & 98^{2} \\ 84^{5} & 69^{5} & 88^{1} & 71^{4} & 67^{2} & 88^{4} & 43^{3} \\ 86^{5} & 72^{5} & 87^{2} & 72^{4} & 70^{2} & 86^{4} & 42^{2} \\ 86^{5} & 73^{5} & 87^{2} & 76^{3} & 70^{2} & 84^{4} & 38^{3} \\ 86^{5} & 73^{5} & 87^{2} & 76^{3} & 70^{2} & 84^{4} & 38^{3} \\ - & - & 84^{1} & 67^{5} & 66^{4} & 69^{5} & 41^{2} \\ 66^{5} & 51^{5} & 77^{1} & 61^{6} & 56^{2} & - & 26^{4} \\ 87^{5} & 67^{5} & 89^{1} & 81^{4} & 68^{1} & 88^{4} & 43^{2}\end{array}$

Fig. 3 Itaconate cluster composition of selected Ustilaginaceae and a phylogenetic tree of these genes. a Phylogenetic tree based on the DNA sequences of itaconate clusters of different Ustilaginaceae. The optimal tree with the sum of branch length $=1.88603985$ is shown. The evolutionary distances are in the units of 0.05 base substitutions per site. $\mathbf{b}$ Itaconate cluster comparison of selected Ustilaginaceae. Numbers given show sequence identity as percentage compared to the reference strain U. maydis MB215 using global protein sequence multiple alignment tool (BLOSUM 62). Superscript number indicate number of exons for each gene. Absent genes are indicated with a dash (-)

[42]. This may explain why $P$. hubeiensis failed to produce itaconate.

In general, the conservation of a protein sequence could point to its evolutionary origin. The comparison showed that among the tested $U$. maydis strains the itaconate cluster is conserved. At the DNA level the clusters in different $U$. maydis strains are $>98 \%$ similar and the clusters of the two $U$. cynodontis strains have $99 \%$ sequence identity on DNA level. For the other species, the sequence identity of proteins encoded by the itaconate and (S)-2-hydroxyparaconate biosynthesis (cyp3, tad1 and adil) and transporters (itp1 and $m t t 1$ ) genes were mostly conserved in a range of $56-89 \%$ compared to the $U$. maydis MB215 sequence. The most divergent protein of the itaconate cluster is Ria1, a transcription factor of approximately 380 amino acids. The annotated $U c \_$ria 1 of both $U$. cynodontis strains encode a transcription factor of 471 amino acids. A conserved helix-loophelix structural motif could be found in all 13 regulators approximately in position 100-AA by SMART analysis, which is a characteristic DNA-binding motif for one of the largest families of dimerizing transcription factors $[44,45]$. The phylogenetic tree of the predicted Ria1 transcriptional regulators is shown in Fig. 4. Ria1 proteins of $U$. maydis species are very closely related. $U$. cynodontis and $U$. xerochloae are closely related [46], which is reflected in the relatedness of their Ria1 proteins.

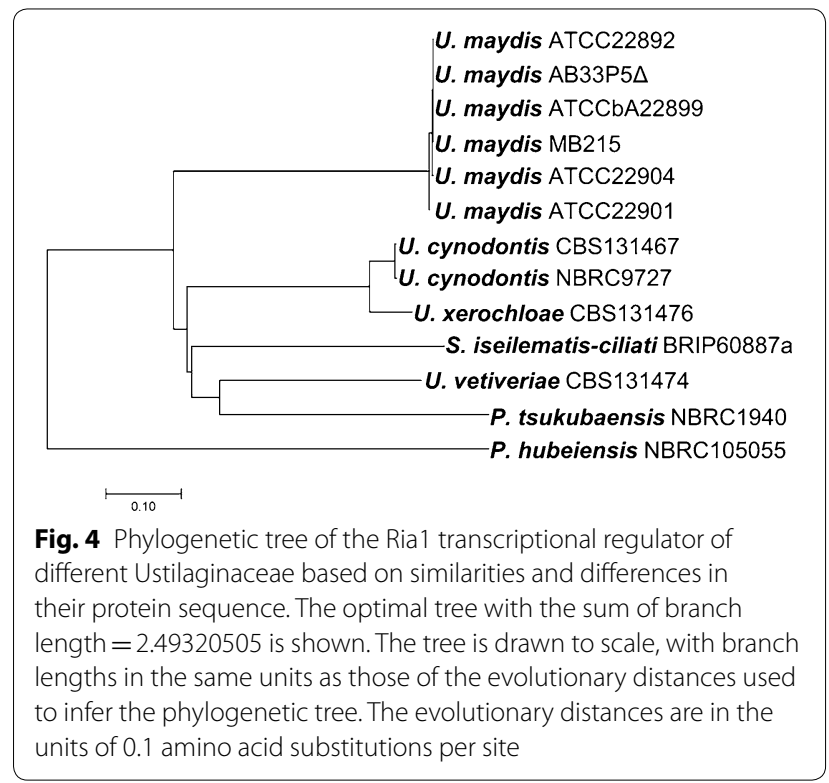


However, $U$. maydis and $U$. vetiveriae are phylogenetically closely related as well [46], even though their Ria1 proteins are only $43 \%$ identical. This may indicate that the amino acid sequence of Rial proteins is evolving faster than its actual function, for which just the DNA-binding motif is essential. The Ria1 sequence of $P$. hubeiensis is phylogenetically the most distant of the species compared. In general, no accurate subcategorization of the transcription factor according the species is possible. A reason might be the aforementioned difficulties in categorization of the Ustilaginaceae.

In summary, all tested strains have the genetic inventory for itaconate biosynthesis, and the synteny of the itaconate cluster is preserved in most of the investigated Ustilaginaceae. $P$. tsukubaensis and $P$. hubeiensis do not possess the complete itaconate cluster, partly explaining the differences in product spectrum. However, the variable itaconate and (S)-2-hydroxyparaconate titer, especially among different $U$. maydis strains with highly similar clusters, could not be explained. As different regulation or expression levels might be responsible for these production differences, the Rial transcriptional regulator of the tested Ustilaginaceae were investigated in more detail.

\section{Inter-species transferability of Ria 1 regulator}

The itaconate clusters of the tested strains are mostly conserved, while production levels of itaconate differ. As one example, the $U$. maydis AB33P5 $\Delta$ gene cluster is 98\% similar at the DNA level to that of $U$. maydis ATCCbA22899; however, strain AB33P5 $\triangle$ does not produce itaconate or $(S)$-2-hydroxyparaconate while strain ATCCbA22899 does. Probably in some strains, like $U$. maydis $\mathrm{AB} 33 \mathrm{P} 5 \Delta$, ria1 is functional but not expressed. To test whether production differences are a result of different regulation, the inter-species transferability of Rial was investigated by overexpression of various ria1 genes to activate the production of itaconate. We chose the itaconate cluster regulator genes Umag_ria1, Uc_ria1, Pt_ria1, and Si_ria1 of $U$. maydis MB215, $U$. cynodontis NBRC9727, P. tsukubaensis, and S. iseilematis-ciliati, respectively, due to their considerable differences in the sequences of both the itaconate cluster and Ria1. These regulators were expressed under control of the constitutive promoter $\mathrm{P}_{\text {etef }}$ in $U$. maydis MB215, $U$. maydis AB33P5 $\Delta, U$. vetiveriae, $U$. xerochloae, $U$. cynodontis CBS131467, U. cynodontis NBRC9727, P. tsukubaensis, P. hubeiensis, and S. iseilematis-ciliati, as well as in the control strain $U$. maydis MB215 $\Delta U$ Umag_ria1. Successful integration was verified by PCR.

All strains tested consumed at least $35 \%$ of the applied glucose after $120 \mathrm{~h}$ and $30 \%$ of the applied glycerol after $384 \mathrm{~h}$ except of $U$. maydis AB33P5 $\Delta$, which used $13 \%$ glycerol (Additional file 2: Fig. S2). A summary of the activation experiments is shown in Fig. 5 and Additional file 3: Fig. S3. The itaconate and (S)-2-hydroxyparaconate production yield (gram product per gram substrate) of the activated strains was determined on both glucose and glycerol (Fig. 6) as well as the malate yield and the estimated relative itatartarate production (Additional file 4: Fig. S4). In $U$. maydis MB215 $\Delta U$ Umag ria1, itaconate production could be restored by expression of all tested regulators (Umag_ria1, Uc_ria1, Pt_ria1, and Si_ria1), demonstrating the functionality of this expression system, as well as their transferability of the genes between related species. It should be noted that quantitative differences in production level may be caused by different copy number, or by the random ectopic integration locus, of the integrated regulator, which were not determined in detail. Thus, these results should be viewed mostly in a qualitative manner. In strains that do not produce itaconate on glucose, such as $U$. maydis AB33P5 (derivative of $U$. maydis $\mathrm{FB} 1), U$. vetiveriae, $P$. tsukubaensis, $P$. hubeiensis, and $S$. iseilematis-ciliati itaconate production could be activated by expression of all tested regulators, except $U c_{-}$ ria1. This suggests that in these wild type strains the itaconate cluster genes are silent, because the regulator gene ria1 is silent and not transcribed. Constitutive expression of the itaconate regulator rial, even originating from different species, activated the expression of the itaconate cluster genes, which resulted in itaconate production.

As already encountered for the wild type strains, $(S)$ 2-hydroxyparaconate and itatartarate production correlated with itaconate production. In general, activation or enhancement of itaconate biosynthesis also activated or enhanced ( $S$ )-2-hydroxyparaconate and itatartarate biosynthesis (Fig. 5, Additional files 3 and 4: Fig. S3 and Fig. S4). An exception is $P$. tsukubaensis that does not possess the (S)-2-hydroxyparaconate biosynthesis genes $r d o 1$ and cyp3, and therefore (S)-2-hydroxyparaconate and itatartarate are not produced in the activated strains. Zambanini et al. showed a negative correlation of itaconate and malate biosynthesis after overexpression of Umag ria1 in $U$. vetiveriae CBS131474 on glycerol [12]. This is in line with our results. However, for the other tested Ustilaginaceae this negative correlation could not be shown, as in most activated strains malate production resembled the wild type level (Fig. 5, Additional file 4: Fig. S4).

Comparing the successfully activated or improved strains, those expressing Uc_ria1 perform considerably less well than strains expressing the other regulators. Deletion of Uc_ria1 in U. cynodontis NBRC9727 completely abolished itaconate production (data not shown), indicating that $U c_{-}$ria1 is essential for itaconate production. However, $U$. cynodontis NBRC9727 $\Delta U U_{\text {crria1 }}$ could not be complemented by Uc_ria1 under control of the 


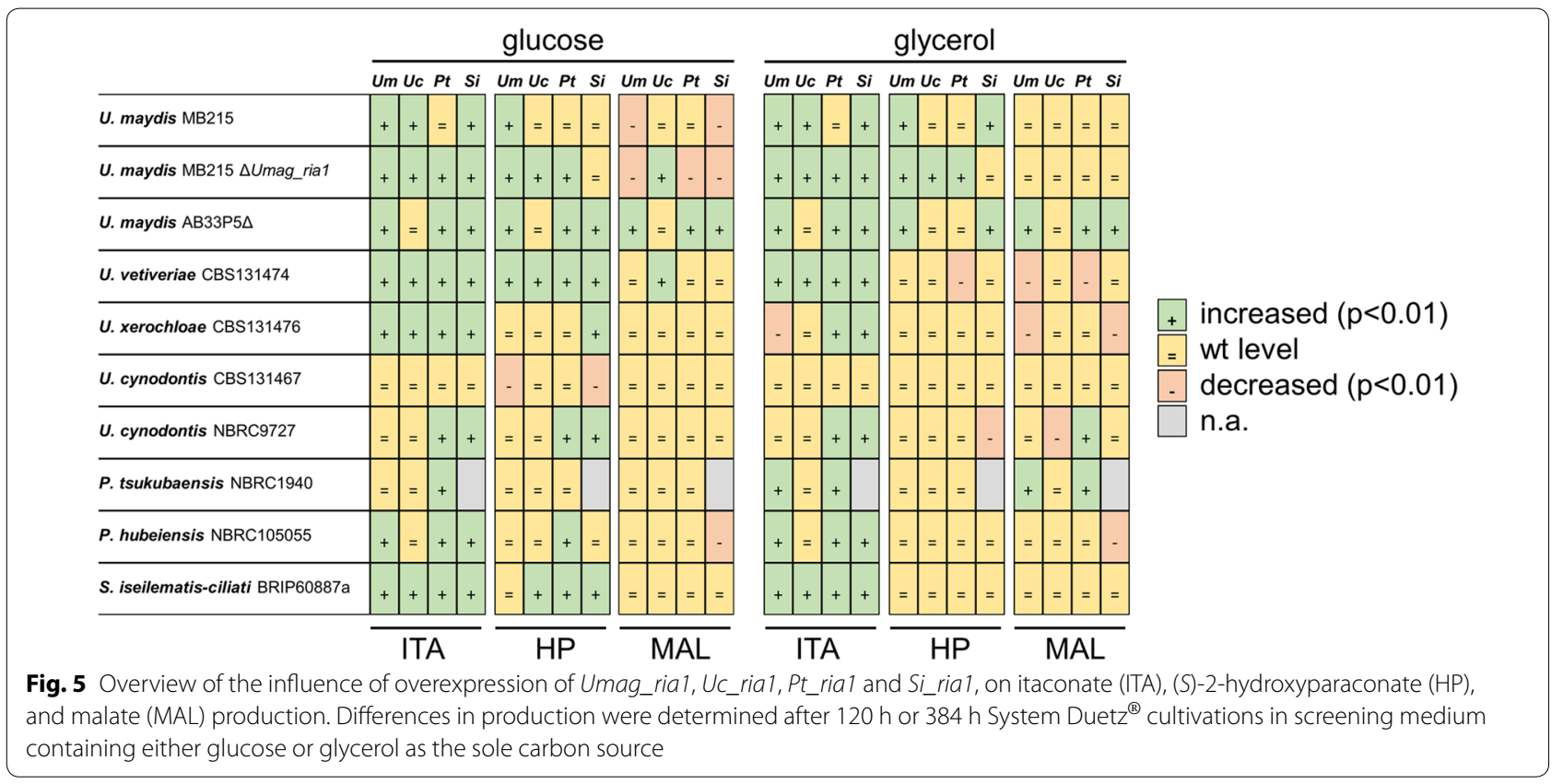

constitutive promoter $\mathrm{P}_{\text {etep }}$ although complementation experiments under control of the native promotor $\mathrm{P}_{U_{\text {c_rial }}}$ and terminator $\mathrm{T}_{U \_ \text {_rial }}$ and a random genome integration was successfully (data not shown). This indicates that the integration locus of genes under control of $\mathrm{P}_{\text {etef }}$ plays a crucial role for heterologous expression in $U$. cynodontis and that the chosen expression cassette design may have affected the outcome of rial overexpression in different hosts. In $U$. cynodontis strains itaconate production could not be considerably enhanced, even by overexpression of the native regulator $U c_{-}$rial. In contrast, strains more closely related phylogenetically with a lower wild type production level, such as $U$. xerochloae, could still enhance itaconate production by overexpression of $U c_{-}$ ria1. Since the $U$. cynodontis strains were the best performing wild types, it might be possible that the natural expression level of the cluster genes is already at a high level, and the rate limiting factor lies upstream of the itaconate production pathway. Alternatively, induction by Ria1 is in $U$. cynodontis already at its maximum.

Although the itaconate production of $P$. tsukubaensis and S. iseilematis-ciliati strains is comparatively low, the regulators $P t_{-}$rial and Si_ria1 seem to be the most universally applicable, since they improved itaconate production in $80 \%$ of the tested strains when cultured on glucose or glycerol. Therefore, Pt_ria1 and Si_ria1 might open new possibilities to activate itaconate production in other species through heterologous gene expression approaches.

In general, the differences in itaconate production in strains expressing the same regulator could have several explanations. The chosen constitutive promoter $\mathrm{P}_{\text {etef }}$ is a modified tef promoter controlling transcription of the gene for the translation elongation factor 2 of $U$. maydis [47]. It may be less efficient in other Ustilaginaceae than in $U$. maydis. However, its functionality was verified in $U$. trichophora [48] and $U$. vetiveriae [12]. As mentioned before, different copy numbers of the integrated regulators can cause differences in transcription levels and therefore in production levels. Especially for results on glycerol showing an overall similar trend than on glucose, different growth kinetics, including, growth rates, and substrate uptake rates can cause differences in itaconate production. The growth rate on glycerol of Ustilaginaceae is lower in comparison to that on glucose, hence less nitrogen for biomass synthesis per time is required, which subsequently influences nitrogen limitation during cultivation. Nitrogen limitation is necessary for natural induction of itaconate production in $U$. maydis [49]. The maximum theoretical yield of itaconate production is directly related to the consumed $\mathrm{C} / \mathrm{N}$ ratio, and thus poor growth (low growth rate) could result in a lower yield given the chosen cultivation time. Altogether, itaconate production could be activated or enhanced by overexpression of Rial originating from a related species, even though the chosen Rial protein sequences are very dissimilar. This is the first time that activation of silent itaconate clusters by overexpression of a cluster-specific transcription factor across species and even genus boundaries was shown.

Since overexpression of Ria1 upregulates all genes of the itaconate core cluster in $U$. maydis MB215 [17], 


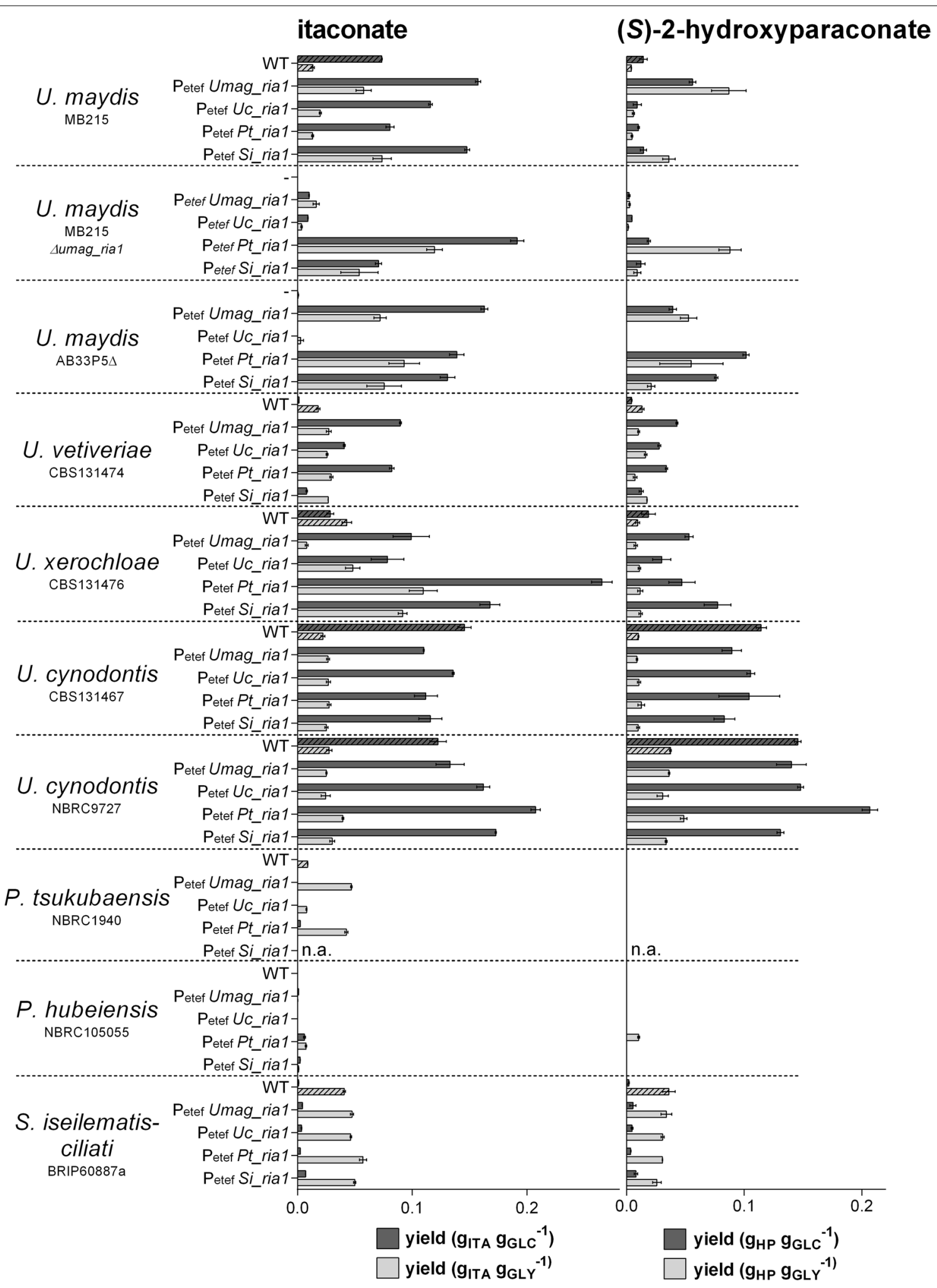

Fig. 6 Itaconate and (S)-2-hydroxyparaconate production by various Ustilaginaceae species and their mutants transformed with Umag_rial, UC_rial, Pt_ria1, Si_ria1. Itaconate ( $\left.g_{\text {ITA }} g_{G L C,}^{-1} g_{\text {ITA }} g_{G L Y}^{-1}\right)$ and (S)-2-hydroxyparaconate $\left(g_{H P} g_{G L C}^{-1} g_{H P P} g_{G L Y}^{-1}\right)$ yield after 120 h or 384 h System Duetz ${ }^{\circledR}$ cultivations in screening medium containing glucose $(G L C)$ and glycerol $(G L Y)$, respectively. A dash (-) indicates the negative control without an overexpression construct. Error bars indicate standard deviation from the mean $(n=3)$ 


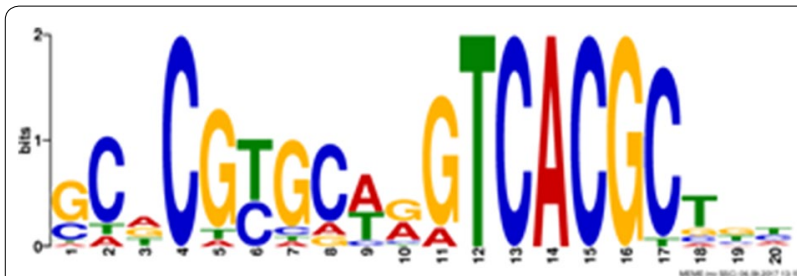

Fig. 7 Common motif within the promoter regions of the itaconate cluster genes in all tested Ustilaginaceae was identified by MEME analysis [50]

promoter regions of the co-regulated genes will likely have a common conserved regulator binding domain. In this study the phylogenetic relatedness and the feasible inter-species transferability of Ria1 regulator originating from related species could be shown. To identify potential common regulatory sequences, in silico analysis for conserved sequence motifs was performed using the MEME algorithm Version 4.12.0 under standard settings [50]. This analysis revealed that promoters of Ria1-regulated genes share a putative conserved Rial binding domain with a short consensus sequence ( $\mathrm{CN}[\mathrm{T} / \mathrm{C}] \mathrm{NNNN}[\mathrm{G} / \mathrm{A}]$ TCACG $[\mathrm{C} / \mathrm{T}]$ ) (Fig. 7). This sequence can be found in all tested Ustilaginaceae in either orientation in the promoter regions of all annotated cluster genes in at least one copy with an average E-value of $1.8 \times 10^{-83}$. Interestingly, none of the ria1 promoters themselves contain this element. Since most of the tested regulators do not seem to be very species-specific, this site likely binds regulators from multiple species. Although the role of this motif as the binding site for Rial needs to be confirmed by biochemical methods, its occurrence in the sequenced wild type strains (U. maydis MB215 (DSM17144), U. vetiveriae CBS131474, U. xerochloae CBS131476, U. cynodontis CBS131467, P. tsukubaensis NBRC1940 and P. hubeiensis NBRC105055, and S. iseilematis-ciliati BRIP60887a) strongly suggests that in spite of the relatively low amino acid sequence similarity of Rial in these species, the function of this regulator is the same.

\section{Conclusion}

This study indicates phenotypically that itaconate production differences among related Ustilaginaceae species are based on different transcriptional regulation of the itaconate cluster genes, governed in turn by the expression level of Ria1. All tested strains have the genetic equipment for itaconate production; also, itaconate non-producers. However, in some strains the itaconate clusters are silent, because the itaconate regulator ria1 is silent. By overexpression of itaconate cluster-specific transcription factors Ria1 originating from related species, we could activate silent itaconate clusters, even though the amino acid sequences of Ria1 regulators are relatively dissimilar. In additional to the silent itaconate clusters being activated, itaconate production in weak producers could be enhanced up to 4-fold. Especially, the activated form of $U$. maydis strain AB33P5 $\Delta$ might be a promising candidate for the combination of biomass degradation and itaconate production in one strain [31]. As such, this study contributes to demonstrating the industrial applicability of Ustilaginaceae for the biotechnological production of itaconate, and also suggests that activation of silent secondary metabolite clusters can be achieved in a range of related species with reduced genetic engineering efforts.

\section{Methods}

\section{Strains and culture conditions}

All strains used in this work are listed in Table 1.

\section{Ria1 overexpression constructs}

To generate the overexpression construct, the backbone of the plasmid $\mathrm{P}_{\text {etef }}$-ria1-cbx from Escherichia coli Top10+Petef Umag_ria1-Cbx was amplified by PCR with the primer pair HT-212 and HT-213 (Table 1, Additional file 5: Table S1). The genes encoding the transcription factors Ria1 from Pseudozyma tsukubaensis, Ustilago cynodontis NBRC9727, and Sporisorium iseilematis-ciliati were amplified by PCR using the primer pairs HT-214/HT-215, HT-218/HT-219, and HT-216/HT-217, respectively (Additional file 5: Table S1). Gibson cloning with backbone and different rial genes was conducted to obtain the plasmids $\mathrm{P}_{\text {etef }} \mathrm{Pt}$ _ria1, $\mathrm{P}_{\text {etef }} \mathrm{Uc}$ _ria1, and $\mathrm{P}_{\text {etef }} \mathrm{Si}$ _ria1, respectively [51]. Enzyme digestion and PCR ensured correct assembly.

\section{Overexpression of Ria 1}

For random integration of the ria1 overexpression constructs into the genome of the different Ustilaginaceae, the different plasmids $\left(\mathrm{P}_{\text {etef }} P t\right.$ ria1, $\mathrm{P}_{\text {etef }} S i$ ria1, $\mathrm{P}_{\text {etef }}$ Uc_ria1 and $\mathrm{P}_{\text {etef }} U m a g \_$rial-cbx) were linearized by SspI except of $\mathrm{P}_{\text {etef }}$ Pt_ria1, which was linearized by BsrgI. Integration of the linearized overexpression construct in the different Ustilaginaceae was conducted by protoplasts transformation according to Tsukuda et al. [52]. To confirm plasmid integration, the ria1 was amplified by PCR using the primer Potef-fwd and Tnos-rev.

Shaking cultures were performed in the System Duetz $^{\circledR}$ (24 well plates) with a filling volume of $1.5 \mathrm{~mL}$ $\left(\mathrm{d}=50 \mathrm{~mm}, \mathrm{n}=300 \mathrm{rpm}, \mathrm{T}=30{ }^{\circ} \mathrm{C}\right.$ and $\left.\Phi=80 \%\right)$ [53]. The screening medium contained $50 \mathrm{~g} \mathrm{~L}^{-1}$ glucose or $100 \mathrm{~g} \mathrm{~L}^{-1}$ glycerol, $0.8 \mathrm{~g} \mathrm{~L}^{-1} \mathrm{NH}_{4} \mathrm{Cl}, 0.2 \mathrm{~g} \mathrm{~L}^{-1}$ $\mathrm{MgSO}_{4} \cdot 7 \mathrm{H}_{2} \mathrm{O}, 0.01 \mathrm{~g} \mathrm{~L}^{-1} \mathrm{FeSO}_{4} \cdot 7 \mathrm{H}_{2} \mathrm{O}, 0.5 \mathrm{~g} \mathrm{~L}^{-1} \mathrm{KH}_{2} \mathrm{PO}_{4}$, $1 \mathrm{~mL} \mathrm{~L}^{-1}$ vitamin solution, $1 \mathrm{~mL} \mathrm{~L}^{-1}$ trace element solution, and as buffer $132 \mathrm{~g} \mathrm{~L}^{-1}$ calcium carbonate [10]. 
Table 1 Strains used in this study

\begin{tabular}{|c|c|c|}
\hline Strain designation & Resistance & $\begin{array}{l}\text { Reference/ } \\
\text { GenBank Accession } \\
\text { number }\end{array}$ \\
\hline 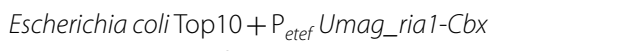 & Ampicillin & {$[54]$} \\
\hline Escherichia coli NEB ${ }^{\circledR}$ 5a Petef Uc_ria1-Cbx & Ampicillin & This study \\
\hline Escherichia coli $\mathrm{NEB}^{\circledR}$ 5a $\mathrm{P}_{\text {etef }}$ Pt_ria1-Cbx & Ampicillin & This study \\
\hline Escherichia coli NEB ${ }^{\circledR} 5$ a P etef Si_ria1-Cbx & Ampicillin & This study \\
\hline $\begin{array}{l}\text { Ustilago maydis DSM17144 } \\
\text { (Ustilago maydis MB215) }\end{array}$ & Wild type & AACP00000000 \\
\hline Ustilago maydis DSM17144 $\mathrm{P}_{\text {etef }}$ Umag_ria1 & Carboxin & This study \\
\hline Ustilago maydis DSM17144 P etef UC_ria1 $_{1}$ & Carboxin & This study \\
\hline Ustilago maydis DSM17144 $\mathrm{P}_{\text {etef }}$ Pt_ria1 & Carboxin & This study \\
\hline Ustilago maydis DSM17144 Petef Si_ria1 & Carboxin & This study \\
\hline Ustilago maydis DSM17144 DUmag_ria1 & Hygromycin & {$[54]$} \\
\hline Ustilago maydis DSM17144 $\triangle$ Umag_ria1 $P_{\text {etef }}$ Umag_ria1 & Hygromycin, carboxin & {$[54]$} \\
\hline Ustilago maydis DSM17144 $\triangle$ Umag_ria1 P etef Uc_ria1 & Hygromycin, carboxin & This study \\
\hline Ustilago maydis DSM17144 $\triangle$ Umag_ria1 P etef $_{\text {Pt_rial }}$ & Hygromycin, carboxin & This study \\
\hline Ustilago maydis DSM17144 $\triangle$ Umag_ria1 $\mathrm{P}_{\text {etef }}$ Si_ria1 & Hygromycin, carboxin & This study \\
\hline Ustilago maydis ATCC 22892 & Wild type & LYOO00000000 \\
\hline Ustilago maydis ATCC22904 & Wild type & LZQT00000000 \\
\hline Ustilago maydis ATCC22901 & Wild type & LZNJ00000000 \\
\hline Ustilago maydis ATCCbA22899 & Wild type & LYZD00000000 \\
\hline Ustilago maydis AB33P5 $\triangle$ & Wild type & {$[30] / L Z Q \cup 00000000$} \\
\hline Ustilago maydis $\mathrm{AB} 33 \mathrm{P} 5 \triangle \mathrm{P}_{\text {etef }}$ Umag_ria1 & Carboxin & This study \\
\hline Ustilago maydis AB33P5 $\triangle \mathrm{P}_{\text {etef }}$ Uc_ria1 & Carboxin & This study \\
\hline Ustilago maydis AB33P5 $\triangle \mathrm{P}_{\text {etef }} P t$ _rial & Carboxin & This study \\
\hline Ustilago maydis AB33P5 $\triangle \mathrm{P}_{\text {etef }}$ Si_rial & Carboxin & This study \\
\hline Ustilago vetiveriae CBS131474 & Wild type & MAIM00000000 \\
\hline Ustilago vetiveriae CBS131474 $\mathrm{P}_{\text {etef }}$ Umag_ria1 & Carboxin & {$[12]$} \\
\hline Ustilago vetiveriae CBS131474 $\mathrm{P}_{\text {etef }}$ Uc_ria1 & Carboxin & This study \\
\hline Ustilago vetiveriae CBS131474 $\mathrm{P}_{\text {etef }}$ Pt_rial & Carboxin & This study \\
\hline Ustilago vetiveriae CBS131474 $\mathrm{P}_{\text {etef }}$ Si_ria1 & Carboxin & This study \\
\hline Ustilago xerochloae CBS131476 & Wild type & MAIN00000000 \\
\hline Ustilago xerochloae CBS131476 P etef Umag_rial & Carboxin & This study \\
\hline Ustilago xerochloae CBS131476 P etef Uc_rial & Carboxin & This study \\
\hline Ustilago xerochloae CBS131476 P etef Pt_ria1 & Carboxin & This study \\
\hline Ustilago xerochloae CBS131476 P $\mathrm{P}_{\text {etef }}$ Si_ria1 & Carboxin & This study \\
\hline Ustilago cynodontis CBS131467 & Wild type & LZQV00000000 \\
\hline Ustilago cynodontis CBS131467 P etef Umag_rial & Carboxin & This study \\
\hline Ustilago cynodontis CBS131467 Petef Uc_ria1 & Carboxin & This study \\
\hline Ustilago cynodontis CBS131467 P etef Pt_ria1 & Carboxin & This study \\
\hline Ustilago cynodontis CBS131467 P etef Si_ria1 & Carboxin & This study \\
\hline Ustilago cynodontis NBRC9727 & Wild type & LZZZ00000000 \\
\hline Ustilago cynodontis NBRC9727 P etef Umag_rial & Carboxin & This study \\
\hline Ustilago cynodontis NBRC9727 Petef Uc_ria1 & Carboxin & This study \\
\hline Ustilago cynodontis NBRC9727 Petef Pt_ria1 & Carboxin & This study \\
\hline Ustilago cynodontis NBRC9727 P etef Si_ria1 & Carboxin & This study \\
\hline $\begin{array}{l}\text { Pseudozyma tsukubaensis } \\
\text { NBRC1940 }\end{array}$ & Wild type & MAIP00000000 \\
\hline Pseudozyma tsukubaensis NBRC1940 $\mathrm{P}_{\text {etef }}$ Umag_ria1 & Carboxin & This study \\
\hline
\end{tabular}


Table 1 (continued)

\begin{tabular}{|c|c|c|}
\hline Strain designation & Resistance & $\begin{array}{l}\text { Reference/ } \\
\text { GenBank Accession } \\
\text { number }\end{array}$ \\
\hline $\begin{array}{l}\text { Pseudozyma tsukubaensis } \\
\text { NBRC1940 Petef Uc_rial }^{\text {Un }}\end{array}$ & Carboxin & This study \\
\hline $\begin{array}{l}\text { Pseudozyma tsukubaensis } \\
\text { NBRC1940 P etef Pt_rial }\end{array}$ & Carboxin & This study \\
\hline $\begin{array}{l}\text { Pseudozyma hubeiensis } \\
\text { NBRC105055 }\end{array}$ & Wild type & MAIO00000000 \\
\hline Pseudozyma hubeiensis NBRC105055 P etef Umag_ria1 & Carboxin & This study \\
\hline $\begin{array}{l}\text { Pseudozyma hubeiensis } \\
\text { NBRC105055 P etef Uc_rial }\end{array}$ & Carboxin & This study \\
\hline $\begin{array}{l}\text { Pseudozyma hubeiensis } \\
\text { NBRC105055 } \mathrm{P}_{\text {etef }} \text { Pt_rial }\end{array}$ & Carboxin & This study \\
\hline $\begin{array}{l}\text { Pseudozyma hubeiensis } \\
\text { NBRC105055 P } \text { etef Si_rial }^{\text {Sil }}\end{array}$ & Carboxin & This study \\
\hline $\begin{array}{l}\text { Sporisorium iseilematis-ciliati } \\
\text { BRIP60887a }\end{array}$ & Wild type & MJEU00000000 \\
\hline Sporisorium iseilematis-ciliati BRIP60887a $\mathrm{P}_{\text {etef }}$ Umag_rial & Carboxin & This study \\
\hline $\begin{array}{l}\text { Sporisorium iseilematis-ciliati } \\
\text { BRIP60887a P etef Uc_rial }\end{array}$ & Carboxin & This study \\
\hline $\begin{array}{l}\text { Sporisorium iseilematis-ciliati } \\
\text { BRIP60887a } \mathrm{P}_{\text {etef }} \text { Pt_rial }\end{array}$ & Carboxin & This study \\
\hline $\begin{array}{l}\text { Sporisorium iseilematis-ciliati } \\
\text { BRIP60887a } \mathrm{P}_{\text {etef }} \text { Si_rial }\end{array}$ & Carboxin & This study \\
\hline
\end{tabular}

Cultures were parallelly inoculated into multiple plates and for each sample point a complete plate was taken as sacrificial sample in order to ensure continuous oxygenation.

\section{Analytical methods}

Cell densities were measured by determining the absorption at $600 \mathrm{~nm}$ with a Unico spectrophotometer 1201.

Products and substrates in the supernatants were analyzed in a DIONEX UltiMate 3000 High Performance Liquid Chromatography System (Thermo Scientific, Germany) with an ISERA Metab AAC column $300 \times 7.8 \mathrm{~mm}$

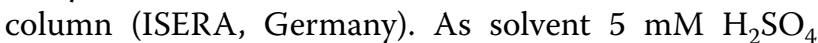
with a flow rate of $0.6 \mathrm{~mL} \mathrm{m^{-1 }}$ and a temperature of $40{ }^{\circ} \mathrm{C}$ was used. All samples were filtered with Acrodisc ${ }^{\circledR}$ Syringe Filters (GHP, $0.20 \mu \mathrm{m}, \varnothing 13 \mathrm{~mm}$ ). Itaconate, (S)-2-hydroxyparaconate, malate, and itatartarate were determined with a DIONEX UltiMate 3000 Variable Wavelength Detector set to $210 \mathrm{~nm}$, glycerol and glucose with a refractive index detector SHODEX RI-101 (Showa Denko Europe $\mathrm{GmbH}$, Germany). Itaconate, malate, (S)-2-hydroxyparaconate, glucose, and glycerol were identified via retention time and UV/RI quotient compared to corresponding standards. Synthesized (S)-2-hydroxyparaconate (purity $\sim 70 \%$ ) was used as the HPLC standard for quantification and hence the indicated
(S)-2-hydroxyparaconate values should be taken as rough estimates only [18]. Since no standards of itatartarate are commercially available this compound was analyzed relatively based on HPLC peak area (mAU*min) using the UV detector. All values are the arithmetic mean of at three biological replicates. Error bars indicate the standard deviation from the mean. Statistical analysis was performed using unequal variances $t$ test with unilateral distribution $(P$ values $<0.01$ were considered significant and indicated in figures with *).

\section{Genome sequencing}

Genomic DNA was isolated by standard phenol-chloroform extraction [55]. Eurofins Genomics (Ebersberg, Germany) created the library using the NEBNext ${ }^{\circledR}$ Ultra DNA Library Prep Kit for Illumina ${ }^{\circledR}$ (Art No E7370), and sequenced the library using an llumina HiSeq 2500 machine with TruSeq SBS kit v3 both according to manufacturer's instructions. The sequencing mode was $1 \times 100$ and the processing used the HiSeq Control software 2.0.12.0 RTA 1.17.21.3 bcl2fastq-1.8.4. Quality check of the sequence data was performed with FastQC (Version 0.11.2). The SPAdes-3.7.0-Linux pipeline was used for de novo genome assembly of single-read libraries and read error or mismatch correction including BayesHammer, IOnHammer, SPAdes, MismatchCorrector, dipSPAdes, and truSPAdes. The k-mer size was determined to 55 
using VelvetOptimiser Version 2.2.5. The Whole Genome Shotgun sequences have been deposited in DDBJ/ENA/ GenBank. Their accession numbers are listed in Table 1.

\section{Phylogenetic analyses}

The evolutionary history of itaconate cluster DNA sequences was inferred using the Neighbor-Joining method [36] after alignment via ClustalW algorithm with the MEGA 7: Molecular Evolutionary Genetics Analysis version 7.0 for bigger datasets Alignment Explorer. The optimal tree with the sum of branch length $=1.88603985$ is shown. The tree is drawn to scale, with branch lengths in the same units as those of the evolutionary distances used to infer the phylogenetic tree. The evolutionary distances were computed using the Maximum Composite Likelihood method [37] and are in the units of the number of base substitutions per site. The analysis involved 13 nucleotide sequences. All positions containing gaps and missing data were eliminated. There were a total of 10874 positions in the final dataset. Evolutionary analyses were conducted in MEGA7 [38].

For the phylogenetic tree of Ria1, protein sequences were aligned via ClustalW (codon) algorithm with MEGA 7 [38]. The evolutionary history was inferred using the Neighbor-Joining method [36]. The optimal tree with the sum of branch length $=2.49320505$ is shown. The tree is drawn to scale, with branch lengths in the same units as those of the evolutionary distances used to infer the phylogenetic tree. The evolutionary distances were computed using the Poisson correction method [56] and are in the units of the number of amino acid substitutions per site. The analysis involved 13 amino acid sequences. All positions containing gaps and missing data were eliminated. There were a total of 269 positions in the final dataset. Evolutionary analyses were conducted in MEGA7 [38].

\section{Additional files}

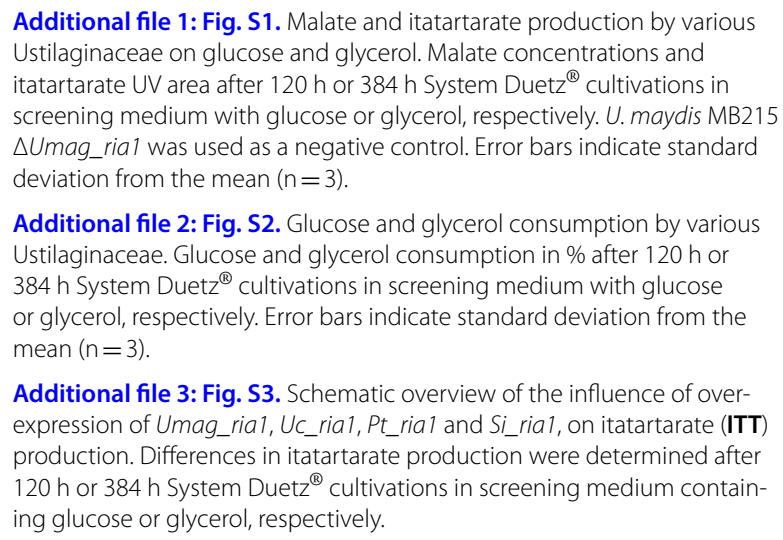

Additional file 2: Fig. S2. Glucose and glycerol consumption by various Ustilaginaceae. Glucose and glycerol consumption in \% after $120 \mathrm{~h}$ or 384 h System Duetz ${ }^{\circledR}$ cultivations in screening medium with glucose or glycerol, respectively. Error bars indicate standard deviation from the mean $(n=3)$.

Additional file 3: Fig. S3. Schematic overview of the influence of overexpression of Umag_ria1, UC_ria1,Pt_ria1 and Si_ria1, on itatartarate (ITT) production. Differences in itatartarate production were determined after 120 h or 384 h System Duetz ${ }^{\circledR}$ cultivations in screening medium containing glucose or glycerol, respectively.

Additional file 4: Fig. S4. Malate and itatartarate production by various Ustilaginaceae and their mutants transformed with Umag_rial, Uc_rial, Pt_ria1, Si_ria1. Malate $\left(g_{\mathrm{Mal}} g_{\mathrm{GLC}}^{-1} g_{\text {TTA }} g_{\mathrm{GLY}}^{-1}\right)$ yield and itatartarate titer after $120 \mathrm{~h}$ or $384 \mathrm{~h}$ System Duetz ${ }^{\mathbb{Q}}$ cultivations in screening medium containing glucose (GLC) and glycerol (GLY), respectively. A dash (-) indicates the negative control without an overexpression construct. Error bars indicate standard deviation from the mean $(n=3)$.

Additional file 5: Table S1. Oligonucleotides used for overexpression constructs.

\section{Authors' contributions}

All authors have contributed significantly to the work. EG and HHT contributed equally to this manuscript. NW, LMB conceived the project. EG and HHT designed experiments and analyzed results. EG wrote the manuscript with the help of HHT. HHT and SM generated overexpression strains. EG performed cultivation experiments and analytics. All authors read and approved the final manuscript.

\section{Author details}

${ }^{1}$ iAMB - Institute of Applied Microbiology, ABBt - Aachen Biology and Biotechnology, RWTH Aachen University, Worringerweg 1, 52074 Aachen, Germany. ${ }^{2}$ BioSC, c/o Forschungszentrum Jülich, 52425 Jülich, Germany.

\section{Acknowledgements}

We thank Sandra Przybilla (Philipps-University Marburg, Germany) for the supply of Ustilago maydis DSM17144 $\triangle$ Umag_rial, Ustilago maydis DSM17144 $\triangle$ Umag_rial $P_{\text {etef }}$ Umag_rial, and Escherichia coli Top10 $+P_{\text {etef }}$ Umag_rial-Cbx and Kerstin Schipper (Heinrich-Heine-University Düsseldorf, Germany) for Ustilago maydis AB33P5 $\triangle$.

\section{Competing interest}

The authors declare that they have no competing interests.

\section{Availability of data and materials}

All data generated or analyzed during this study are included in this published article and its supplementary information files.

\section{Consent for publication}

Not applicable.

\section{Ethics approval and consent to participate}

Not applicable.

\section{Funding}

The scientific activities of the Bioeconomy Science Center were supported financially by the Ministry of Innovation, Science and Research within the framework of the NRW Strategieprojekt BioSC (No. 578 313/323-400-002 13). This work was supported by the Excellence Initiative of the German federal and state governments as a part of the Cluster of Excellence'Tailor-Made Fuels from Biomass' and by the "Bundesministerium für Ernährung und Landwirtschaft" (BMEL), through the project manager "Fachagentur Nachwachsende Rohstoffe e.V." (FNR) as part of the ERA-IB initiative. The funders had no role in study design, data collection and interpretation, or the decision to submit the work for publication.

\section{Publisher's Note}

Springer Nature remains neutral with regard to jurisdictional claims in published maps and institutional affiliations.

Received: 3 May 2018 Accepted: 16 July 2018

Published online: 28 July 2018

\section{References}

1. Brakhage AA, Schroeckh V. Fungal secondary metabolites-strategies to activate silent gene clusters. Fungal Genet Biol. 2011;48:15-22. 
2. Keller NP, Turner G, Bennett JW. Fungal secondary metabolism—-from biochemistry to genomics. Nat Rev Microbiol. 2005;3:937-47.

3. Lazzarini A, Cavaletti L, Toppo G, Marinelli F. Rare genera of actinomycetes as potential producers of new antibiotics. Antonie Van Leeuwenhoek. 2000;78:399-405.

4. Verpoorte R. Secondary metabolism. In: Verpoorte R, Alfermann AW, editors. Metabolic engineering of plant secondary metabolism. Dordrecht: Springer; 2000. p. 1-29.

5. Smith DJ, Burnham MK, Bull JH, Hodgson JE, Ward JM, Browne P, Brown J, Barton B, Earl AJ, Turner G. Beta-lactam antibiotic biosynthetic genes have been conserved in clusters in prokaryotes and eukaryotes. EMBO J. 1990;9:741-7.

6. Trail F, Mahanti N, Rarick M, Mehigh R, Liang SH, Zhou R, Linz JE. Physical and transcriptional map of an aflatoxin gene cluster in Aspergillus parasiticus and functional disruption of a gene involved early in the aflatoxin pathway. Appl Environ Microbiol. 1995;61:2665-73.

7. Blažič M, Starcevic A, Lisfi M, Baranasic D, Goranovič D, Fujs Š, Kuščer E, Kosec G, Petković H, Cullum J, et al. Annotation of the modular polyketide synthase and nonribosomal peptide synthetase gene clusters in the genome of Streptomyces tsukubaensis NRRL18488. Appl Environ Microbiol. 2012:78:8183-90.

8. Brakhage AA. Regulation of fungal secondary metabolism. Nat Rev Microbiol. 2013;11:21-32.

9. Kinoshita K. Über eine neue Aspergillus Art, Asp. itaconicus nov. spec. J Plant Res. 1931:45:45-60.

10. Geiser E, Wiebach V, Wierckx N, Blank LM. Prospecting the biodiversity of the fungal family Ustilaginaceae for the production of value-added chemicals. BMC Fung Biol Biotech. 2014;1:2.

11. Guevarra ED, Tabuchi T. Accumulation of itaconic, 2-hydroxyparaconic, itatartaric, and malic acids by strains of the genus Ustilago. Agric Biol Chem. 1990;54:2353-8.

12. Zambanini T, Hosseinpour Tehrani H, Geiser E, Merker D, Schleese $\mathrm{S}$, Krabbe J, Buescher JM, Meurer G, Wierckx N, Blank LM. Efficient itaconic acid production from glycerol with Ustilago vetiveriae TZ1. Biotechnol Biofuels. 2017;10:131.

13. Okabe M, Lies D, Kanamasa S, Park EY. Biotechnological production of itaconic acid and its biosynthesis in Aspergillus terreus. Appl Microbiol Biotechnol. 2009;84:597-606.

14. Werpy T, Petersen G, Aden A, Bozell J, Holladay J, White J, Manheim A, Eliot $D$, Lasure $L$, Jones $S$. Top value added chemicals from biomass. Volume 1 -results of screening for potential candidates from sugars and synthesis gas. In: DTIC Document; 2004.

15. Geilen FMA, Engendahl B, Harwardt A, Marquardt W, Klankermayer J, Leitner W. Selective and flexible transformation of biomass-derived platform chemicals by a multifunctional catalytic system. Angew Chem. 2010;122:5642-6

16. Leitner W, Klankermayer J, Pischinger S, Pitsch H, Kohse-Hoinghaus K. Advanced biofuels and beyond: chemistry solutions for propulsion and production. Angew Chem Int Ed Engl. 2017;56:5412-52.

17. Geiser E, Przybilla SK, Friedrich A, Buckel W, Wierckx N, Blank LM, Bolker M. Ustilago maydis produces itaconic acid via the unusual intermediate trans-aconitate. Microb Biotechnol. 2016;9:116-26.

18. Geiser E, Przybilla SK, Engel M, Kleineberg W, Büttner L, Sarikaya E, Hartog Td, Klankermayer J, Leitner W, Bölker M, et al. Genetic and biochemical insights into the itaconate pathway of Ustilago maydis enable enhanced production. Metab Eng. 2016;38:427-35.

19. Guevarra ED, Tabuchi T. Production of 2-hydroxyparaconic and itatartaric acids by Ustilago cynodontis and simple recovery process of the acids. Agric Biol Chem Tokyo. 1990;54:2359-65.

20. Zheng Y, Kief J, Auffarth K, Farfsing JW, Mahlert M, Nieto F, Basse CW. The Ustilago maydis $\mathrm{Cys}_{2} \mathrm{His}_{2}$-type zinc finger transcription factor Mzr1 regulates fungal gene expression during the biotrophic growth stage. Mol Microbiol. 2008:68:1450-70

21. Tollot M, Assmann D, Becker C, Altmuller J, Dutheil JY, Wegner CE, Kahmann R. The WOPR protein Ros1 Is a master regulator of sporogenesis and late effector gene expression in the maize pathogen Ustilago maydis. PLoS Pathog. 2016:12:e1005697.

22. Lanver D, Muller AN, Happel P, Schweizer G, Haas FB, Franitza M, Pellegrin C, Reissmann S, Altmuller J, Rensing SA, et al. The biotrophic development of Ustilago maydis studied by RNA-seq analysis. Plant Cell. 2018;30:300-23.
23. Hertweck C. Hidden biosynthetic treasures brought to light. Nat Chem Biol. 2009;5:450-2.

24. Bergmann S, Schumann J, Scherlach K, Lange C, Brakhage AA, Hertweck C. Genomics-driven discovery of PKS-NRPS hybrid metabolites from Aspergillus nidulans. Nat Chem Biol. 2007:3:213-7.

25. Khaldi N, Seifuddin FT, Turner G, Haft D, Nierman WC, Wolfe KH, Fedorova ND. SMURF: genomic mapping of fungal secondary metabolite clusters. Fungal Genet Biol. 2010;47:736-41.

26. Medema MH, Kottmann R, Yilmaz P, Cummings M, Biggins JB, Blin K, de Bruijn I, Chooi YH, Claesen J, Coates RC, et al. Minimum information about a biosynthetic gene cluster. Nat Chem Biol. 2015;11:625-31.

27. Medema MH, Blin K, Cimermancic P, de Jager V, Zakrzewski P, Fischbach MA, Weber T, Takano E, Breitling R. antiSMASH: rapid identification, annotation and analysis of secondary metabolite biosynthesis gene clusters in bacterial and fungal genome sequences. Nucleic Acids Res. 2011:39:339-46.

28. Priebe S, Linde J, Albrecht D, Guthke R, Brakhage AA. FungiFun: a webbased application for functional categorization of fungal genes and proteins. Fungal Genet Biol. 2011;48:353-8.

29. Geiser E, Ludwig F, Zambanini T, Wierckx N, Blank LM. Draft genome sequences of itaconate-producing Ustilaginaceae. Genome Announc. 2016:4:e01291.

30. Sarkari P, Reindl M, Stock J, Müller O, Kahmann R, Feldbrügge M, Schipper K. Improved expression of single-chain antibodies in Ustilago maydis. J Biotechnol. 2014;191:165-75.

31. Geiser E, Reindl M, Blank LM, Feldbrugge M, Wierckx N, Schipper K. Activating intrinsic CAZymes of the smut fungus Ustilago maydis for the degradation of plant cell wall components. Appl Environ Microbiol. 2016:82:5174-85.

32. Sanchez S, Chavez A, Forero A, Garcia-Huante Y, Romero A, Sanchez M, Rocha D, Sanchez B, Avalos M, Guzman-Trampe S, et al. Carbon source regulation of antibiotic production. J Antibiot. 2010;63:442-59.

33. Altschul SF, Madden TL, Schaffer AA, Zhang J, Zhang Z, Miller W, Lipman DJ. Gapped BLAST and PSI-BLAST: a new generation of protein database search programs. Nucleic Acids Res. 1997;25:3389-402.

34. Stanke M, Steinkamp R, Waack S, Morgenstern B. AUGUSTUS: a web server for gene finding in eukaryotes. Nucleic Acids Res. 2004:32:309-12.

35. Henikoff S, Henikoff JG. Amino acid substitution matrices from protein blocks. Proc Natl Acad Sci USA. 1992;89:10915-9.

36. Saitou N, Nei M. The neighbor-joining method: a new method for reconstructing phylogenetic trees. Mol Biol Evol. 1987;4:406-25.

37. Tamura K, Nei M, Kumar S. Prospects for inferring very large phylogenies by using the neighbor-joining method. Proc Natl Acad Sci USA. 2004;101:11030-5

38. Kumar S, Stecher G, Tamura K. MEGA7: molecular evolutionary genetics analysis version 7.0 for bigger datasets. Mol Biol Evol. 2016;33:1870-4.

39. Wang QM, Begerow D, Groenewald M, Liu XZ, Theelen B, Bai FY, Boekhout T. Multigene phylogeny and taxonomic revision of yeasts and related fungi in the Ustilaginomycotina. Stud Mycol. 2015;81:55-83.

40. McTaggart AR, Shivas RG, Boekhout T, Oberwinkler F, Vánky K, Pennycook SR, Begerow D. Mycosarcoma (Ustilaginaceae), a resurrected generic name for corn smut (Ustilago maydis) and its close relatives with hypertrophied, tubular sori. IMA Fungus. 2016;7:309-15.

41. McLaughlin D, Spatafora JW. Systematics and evolution. Berlin: Springer; 2014

42. Geiser E. Itaconic acid production by Ustilago maydis, vol. 1. Aachen: Apprimus Verlag; 2015

43. Palmieri F. The mitochondrial transporter family (SLC25): physiological and pathological implications. Pflugers Arch. 2004;447:689-709.

44. Murre C, Bain G, van Dijk MA, Engel I, Furnari BA, Massari ME, Matthews $J R$, Quong MW, Rivera RR, Stuiver MH. Structure and function of helixloop-helix proteins. Biochim Biophys Acta. 1994;1218:129-35.

45. Letunic I, Doerks T, Bork P. SMART: recent updates, new developments and status in 2015. Nucleic Acids Res. 2015;43:257-60.

46. Stoll M, Piepenbring M, Begerow D, Oberwinkler F. Molecular phylogeny of Ustilago and Sporisorium species (Basidiomycota, Ustilaginales) based on internal transcribed spacer (ITS) sequences. Can J Bot. 2003:81:976-84. 
47. Spellig T, Bottin A, Kahmann R. Green fluorescent protein (GFP) as a new vital marker in the phytopathogenic fungus Ustilago maydis. Mol Genet Genomics. 1996;252:503-9.

48. Zambanini T, Tehrani HH, Geiser E, Sonntag CS, Buescher JM, Meurer G, Wierckx N, Blank LM. Metabolic engineering of Ustilago trichophora TZ1 for improved malic acid production. Metab Eng Commun. 2017;4:12-21.

49. Maassen N, Panakova M, Wierckx N, Geiser E, Zimmermann M, Bölker M, Klinner U, Blank LM. Influence of carbon and nitrogen concentration on itaconic acid production by the smut fungus Ustilago maydis. Eng Life Sci. 2013;14:129-34.

50. Bailey TL, Boden M, Buske FA, Frith M, Grant CE, Clementi L, Ren J, Li WW Noble WS. MEME SUITE: tools for motif discovery and searching. Nucleic Acids Res. 2009;37:202-8.

51. Gibson DG, Young L, Chuang RY, Venter JC, Hutchison CA 3rd, Smith HO Enzymatic assembly of DNA molecules up to several hundred kilobases. Nat Methods. 2009;6:343-5.
52. Tsukuda T, Carleton S, Fotheringham S, Holloman WK. Isolation and characterization of an autonomously replicating sequence from Ustilago maydis. Mol Cell Biol. 1988;8:3703-9.

53. Duetz WA, Ruedi L, Hermann R, O'Connor K, Büchs J, Witholt B. Methods for intense aeration, growth, storage, and replication of bacterial strains in microtiter plates. Appl Environ Microbiol. 2000;66:2641-6.

54. Przybilla S. Genetische und biochemische Charakterisierung der Itaconsäure-Biosynthese in Ustilago maydis. Dissertation. Phillips University Marburg, Germany; 2014

55. Chomczynski P, Sacchi N. Single-step method of RNA isolation by acid guanidinium thiocyanate-phenol-chloroform extraction. Anal Biochem. 1987;162:156-9.

56. Zuckerkandl E, Pauling L. Evolutionary divergence and convergence in proteins. In: Bryson V, Vogel HJ, editors. Evolving genes and proteins. Cambridge: Academic Press; 1965. p. 97-166.
Ready to submit your research? Choose BMC and benefit from:

- fast, convenient online submission

- thorough peer review by experienced researchers in your field

- rapid publication on acceptance

- support for research data, including large and complex data types

- gold Open Access which fosters wider collaboration and increased citations

- maximum visibility for your research: over $100 \mathrm{M}$ website views per year

At BMC, research is always in progress.

Learn more biomedcentral.com/submissions 